\title{
Co-occurrence of bilateral pneumothorax and pneumoperitoneum
}

\author{
Junji Ichinose (10 , Yosuke Matsuura, Masayuki Nakao, Mingyon Mun
}

Department of Thoracic Surgical Oncology, Cancer Institute Hospital of Japanese Foundation for Cancer Research, Tokyo, Japan

\section{Correspondence to \\ Dr Junji Ichinose;}

jichinose-tky@umin.net

Accepted 4 March 2020

\section{DESCRIPTION}

The most common cause of pneumoperitoneum is a perforated abdominal organ caused by an ulcer, tumour or trauma. Gastrointestinal endoscopy and peritoneal dialysis catheter placement can also cause abdominal free air. Moreover, there are several thoracic causes, including mechanical ventilation, cardiopulmonary resuscitation, pneumomediastinum and pneumothorax. ${ }^{1}$

We present the case of a man in his 50s who presented with co-occurrence of bilateral pneumothorax and pneumoperitoneum.

A man in his 50s who was a heavy smoker presented with sudden dyspnoea. Five years ago, he underwent chemoradiotherapy for esophageal cancer, and 2 years ago, he underwent esophageal bypass surgery for esophagobronchial fistula. For the procedure, the stomach was brought up to the neck through a retrosternal tunnel. Esophageal bypass surgery was performed through the neck and abdominal incision.

Chest and abdominal radiographies revealed bilateral lung collapse, pleural effusion and free air under the diaphragm (figure 1A). We performed bilateral thoracic tube drainage. CT revealed bilateral pneumothorax and pneumoperitoneum

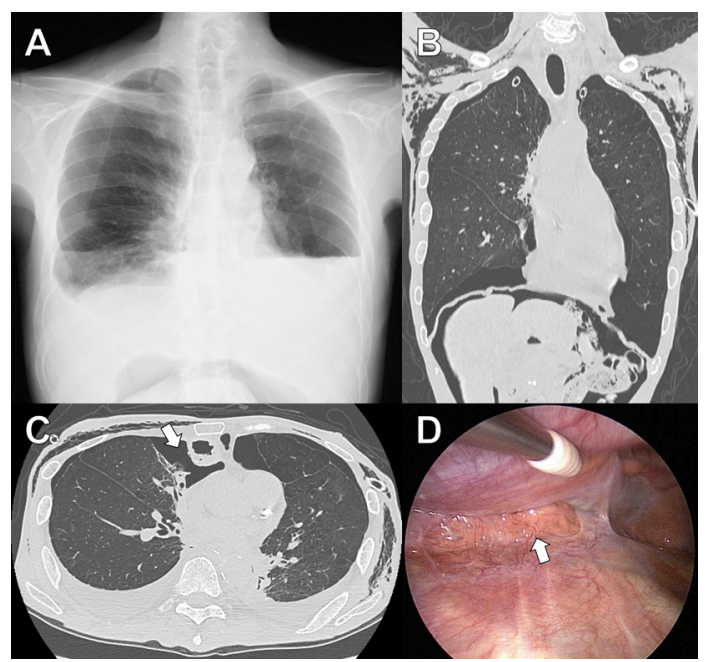

(c) BMJ Publishing Group Limited 2020. No commercial re-use. See rights and permissions. Published by BMJ.

\footnotetext{
To cite: Ichinose J, Matsuura Y, Nakao M, et al. BMJ Case Rep 2020;13:e234628. doi:10.1136/bcr-2020234628
} Figure 1 (A) Chest X-ray on admission shows bilateral pneumothorax, pleural effusion and abdominal air. (B) CT of the chest after tube drainage shows bilateral pneumothorax, pneumohypoderma and pneumoperitoneum. (C) CT revealed the defect of bilateral mediastinal pleura around the lifted stomach (arrow). (D) Thoracoscopic examination of the mediastinal pleura opening, and direct observation of the stomach and omentum (arrow).
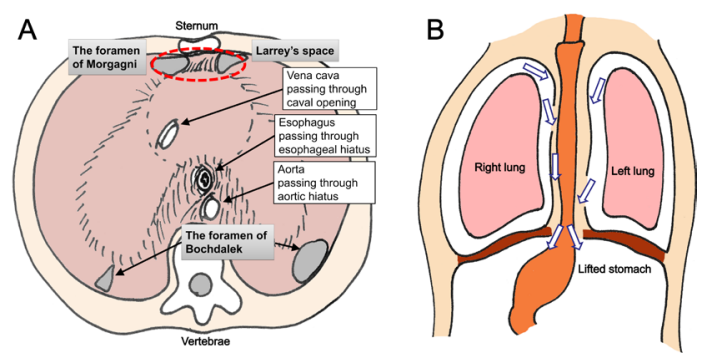

Figure 2 This figure was drawn by one of the authors, Dr Ichinose. (A) Diaphragm, view from below, showing openings. Hernia of the foramen of Bochdalek, the most common congenital diaphragm hernia in $95 \%$ of cases, is followed by retrosternal hernia (Morgagni-Larrey hernia) and esophageal hernia. The patient had the pleural and peritoneal connection in the retrosternal space (red circle). (B) Thoracic cavity air can penetrate the abdominal cavity through the mediastinal pleura opening and hiatus around the stomach lifted through a retrosternal tunnel (arrow).

(figure 1B). Furthermore, multiple bullae were found in the bilateral apex. CT revealed defects in the bilateral mediastinal pleura around the lifted stomach (figure 1C). No abdominal symptoms or findings suggestive of perforated abdominal viscus were observed; therefore, we presumed that air leaks from the bullae had penetrated into the abdominal cavity through the mediastinal pleura opening and hiatus around the lifted stomach (figure 2). After a week, no decrease was observed in the air leakage from the bilateral chest drains. First, we performed left-side thoracoscopic bullectomy because of severe air leakage from the left drain. We located the mediastinal pleura opening and directly observed the stomach and omentum (figure 1D). Although air leakage from the left drain ceased postoperatively, air leakage from the right drain continued. One week after the first surgery, we performed rightside thoracoscopic bullectomy. The air leakage stopped and intra-abdominal free air eventually disappeared. The patient had an uneventful postoperative course and was discharged.

The bilateral pleura appeared open during the 
pneumoperitoneum occurrence have been reported. ${ }^{2-4}$ Clinicians should recognise that thoracic cavity air can penetrate the abdominal cavity through the pleuro-peritoneal communication, which is either congenital or acquired, especially in patients who have undergone esophageal surgery.

\section{Learning points}

- Thoracic cavity air can penetrate the abdominal cavity through the pleuro-peritoneal communication, especially in patients who have undergone esophageal surgery.

- The unilateral air leak can cause bilateral pneumothorax in patients with a pleuro-pleural communication.

Contributors $\mathrm{J}$ contributed to the planning, data collection, analysis and writing of the manuscript. YM, MN and MM contributed to the review of the manuscript.
Funding The authors have not declared a specific grant for this research from any funding agency in the public, commercial or not-for-profit sectors.

Competing interests None declared.

Patient consent for publication Obtained

Provenance and peer review Not commissioned; externally peer reviewed.

\section{ORCID iD}

Junji Ichinose http://orcid.org/0000-0002-3630-5223

\section{REFERENCES}

1 Mularski RA, Sippel JM, Osborne ML. Pneumoperitoneum: a review of nonsurgical causes. Crit Care Med 2000;28:2638-44.

2 Hakim SY, Abdelrahman H, Mudali IN, et al. Pneumoperitoneum in a patient with pneumothorax and blunt neck trauma. Int J Surg Case Rep 2014;5:1106-9.

3 Kusagaya H, Fujisawa T, Enomoto N, et al. Co-occurrence of pneumoperitoneum and pneumothorax in a patient with Pleuroparenchymal fibroelastosis. Am J Respir Crit Care Med 2015;191:1200-1.

4 Yoshiyasu N, Sato S, Hirose M, et al. Bilateral pneumothorax and pneumoperitoneum one year after thoracoscopic esophagectomy. Ann Thorac Surg 2018;105:e275.

Copyright 2020 BMJ Publishing Group. All rights reserved. For permission to reuse any of this content visit

https://www.bmj.com/company/products-services/rights-and-licensing/permissions/

BMJ Case Report Fellows may re-use this article for personal use and teaching without any further permission.

Become a Fellow of BMJ Case Reports today and you can:

- Submit as many cases as you like

- Enjoy fast sympathetic peer review and rapid publication of accepted articles

- Access all the published articles

- Re-use any of the published material for personal use and teaching without further permission

Customer Service

If you have any further queries about your subscription, please contact our customer services team on +44 (0) 2071111105 or via email at support@bmj.com.

Visit casereports.bmj.com for more articles like this and to become a Fellow 